\title{
The National Sericultural Utopia and Debates on the Acclimatization of Plants in New-born Belgium (1830-1865)
}

\section{Denis Diagre-Vanderpelen}

Meise Botanic Garden; Université Libre de Bruxelles, Belgium; Service général de l'Enseignement supérieur et de la Recherche scientifique, Fédération Wallonie-Bruxelles, Belgium

denis.diagre@botanicgardenmeise.be

Abstract: This two-folded contribution firstly addresses the little-known history of an agricultural utopia that took over the newly born Belgium. The history of the Belgian sericultural utopia is not anecdotal, however, it was based on the conviction that it was possible to acclimatize exotic species. This conviction has a long history that is depicted in the second part of this research. The permanence in time of this hope is explained by various factors: famous supporters, a lexical fog, experiments considered successful, routines, agricultural crisis, etc. They kept alive the dream of acclimatization carried out by the French Enlightenment, but not only. Yet, in the first decades of the nineteenth century, the zealots of the famous André Thouin confronted those-early phytogeographers, or not-who rejected acclimatization more often. It might even be that biological nationalism militated against acclimatization, as showed the International Congress of Horticulture in Brussels (1864), which constitutes the chronological milestone of this research.

Keywords: silk industry; Belgium; acclimatization; naturalization 


\section{Introduction}

The issue we propose exploring in these pages is that of debates on the acclimatization of exotic plants in Belgium during the first few decades of existence of this country, which was founded in 1830. We will enter through a well forgotten back door: the sericultural utopia inhabited for several decades by a section of the Kingdom's elites, a utopia whose existence and destiny were intimately tied to the faith, or lack of it, in the possibility of acclimatizing a species, or a group of species of the genus Morus L. to the Belgian climate.

Acclimatize exotic plant species, and we shall see how the word itself could lead to confusion and to what extent this will affect our story, had become an important issue for European countries. ${ }^{1}$ In the eighteenth century, Carl Linnaeus even made acclimatization one of botanists' main missions. ${ }^{2}$ Less than a century later, Belgium had not escaped this project's siren calls. Firstly, because during the nineteenth century it ranked as a great horticultural nation: at that time plant hunters commissioned by Belgium horticulturists battled the tropics to bring home plants that would soon, it was hoped, decorate European gardens or even feed people. Moreover, the nurseries experienced plant flexibility almost daily in producing novelties thus spurring the passion of the enthusiasts. Simultaneously horticultural societies were proliferating in Belgium, showing that the passion for exotic plants had won over the new ruling class, the bourgeoisie. So, a market and a specialized press reflecting the horticultural and scientific concepts and theories in vogue in foreign countries emerged and developed rapidly. ${ }^{3}$ But that is not all. Recently separated from the Netherlands, and cut off from its former markets and colonies, there was an urgent need for Belgium to develop its economy: its industry, first of all, but not forgetting the above mentioned agriculture, which was undergoing a potentially precarious

\footnotetext{
${ }^{1}$ Andrée Corvol, Les arbres voyageurs (Paris: Robert Laffont, 2005), 107 ff. and 156 ff.; Lorelai Kury, Histoire naturelle et voyages scientifiques (1780-1830) (Paris: LHarmattan, 2001), 209 ff.; Lorelai Kury, "André Thouin et la nature exotique au Jardin des Plantes," in Le jardin entre science et représentation, ed. Jean-Louis Fischer, 255-65 (Paris: Editions du CTHS, 1999); Donald P. McCracken, Gardens of Empire. Botanical Institutions of the Victorian British Empire (London-Washington: Leicester University Press, 1997), 1-16.

2 Richard Drayton, Nature's Government. Science, Imperial Britain, and the "Improvement" of the World (New Haven-London: Yale University Press, 2000), 71-6.

${ }^{3}$ Denis Diagre-Vanderpelen, The Botanic Garden of Brussels (1826-1912): Reflection of a Changing Nation (Meise: National Botanic Garden of Belgium, 2011), 17-28; Denis Diagre, "Les 'plant-hunters' belges durant le règne de Léopold 1er (1831-1870): succès et paradoxe," Circumscribere. International Journal for the History of Science 9 (2011): 78-99.
} 
situation. ${ }^{4}$ In this context of the creation of a national economy, or the "nationalization" of the economy, where industry captured much of the politicians' attention, but where the physiocratic echoes of the previous century could still be heard on a regular basis, ${ }^{6}$ for members of the social elite finding a new agricultural or agro-industrial resource constituted patriotism or even philanthropy. ${ }^{7}$ Moreover, the potato blight ${ }^{8}$ would strike the whole of Europe shortly before the middle of the nineteenth century, conferring a very tangible reality to an ancestral fear, omnipresent in the minds of the people and the authorities: famine. Although the idea that the richness of foreign flora's had brought about and would once again bring about wellbeing in "civilized" countries, in other words those capable of controlling "nature,"10 had never actually disappeared, it now regained a sense of urgency. According to some proponents of this idea, "nature" had been created for humans, to exercise their intelligence, their brilliance. ${ }^{11}$

Thus, in this century, heir to the Age of Enlightenment, ${ }^{12}$ a century inhabited by the idea of movement, progress, and a type of faith in science, ${ }^{13}$ Charles Morren, Professor of botany at the University of Liège, was able to exclaim confidently in an official publication that: "The word impossible has really lost its value in horticulture, and forced or delayed crops ... have made

\footnotetext{
${ }^{4}$ Christian Vandenbroeke, "La deuxième expansion agricole et l'industrialisation: le 18e et la première moitié du 19e siècle," in L'agriculture en Belgique hier et aujourd'hui, ed. Adriaan Verhulst and Georges Bublot, 29-39 (Bruxelles: Fonds Mercator/Cultura/Ministère de l'Agriculture/Office National des Débouchés Agricoles et Horticoles, 1980); Els Witte, "La construction de la Belgique 1828-1847," in Nouvelle histoire de Belgique: 1830-1905, ed. Els Witte, Eliane Gubin, Jean-Pierre Nandrin and Gita Deneckere, 1-216 (Bruxelles: Complexe Editions, 2005) 135-44; Eric Vanhaute and Leen Van Molle, "Het einde van de overlevingslandbouw, 1750-1880," in Leven van het land. Boeren in België, 17502000, ed. Yves Segers and Leen Van Molle, 13-48 (Leuven: Davidsfonds, 2000), 15-35.

5 Els Witte, "La construction de la Belgique 1828-1847," 125.

6 See also Marie-Noëlle Bourguet, "La collecte du monde: voyages et histoire naturelle (fin XVIIIe siècle-début XIXe siècle)," in Le Muséum au premier siècle de son histoire, ed. Claude Blanckaert, Claudine Cohen, Pietro Corsi and Jean-Louis Fischer, 163-196 (Paris: Editions du MNHN, 1997), 182 ff.; Vanhaute and Van Molle, "Het einde van de overlevingslandbouw," 15-35.

7 Kury, "André Thouin et la nature," 260, 264-65.

8 Witte, "La construction de la Belgique 1828-1847," 142.

${ }^{9}$ Charles Morren, "Rapport sur les légumes, produits agricoles cultivés comme objets de collection, les plantes rares et fleurs d'ornement et les instruments d'horticulture, constituant les deuxième, troisième, quatrième et cinquièmes classes du programme," in Rapport sur l'exposition nationale des produits de l'agriculture et de l'horticulture de 1848, 257-311 (Bruxelles: Parent, 1849), 282; Kury, "André Thouin et la nature," 264-65.

${ }^{10}$ Kury, "André Thouin et la nature," 255-56.

${ }^{11}$ Charles Naudin, "Un mot à propos de la naturalisation des végétaux exotiques," Flore des Serres et des Jardins de l'Europe 11 (1856), 104.

${ }^{12}$ For an in-depth description of the relationship between science and the Enlightenment, see Emma Spary, Le jardin d'Utopie, l'histoire naturelle en France de l'Ancien Régime à la Révolution (Paris: Muséum national d'Histoire naturelle, 2005), $127 \mathrm{ff}$.

${ }_{13}$ Guillaume Carnino, L'Invention de la science. La nouvelle religion de l'âge industriel (Paris: Éditions du Seuil, 2015), 203-56.
} 
it abundantly clear to what extent art can prevail over nature here." ${ }^{14}$ This type of rhetoric was not rare in the Belgian press in the mid-nineteenth century. It conveyed and established the numerous hopes that constitute the very core of our question.

Lorelai Kury, among others, pointed out that one of these hopes, if not the very origin of these hopes, was acclimatization-sometimes referred to as naturalization, as we shall see. ${ }^{15}$ We only need to look at the numerous gardens and societies dedicated to this purpose in the course of the nineteenth century, one of the most famous of which was the garden that the Société d'Acclimatation (Society of Acclimatization), founded in 1854, was to establish in Paris. ${ }^{16}$ The conviction that a life form could adapt to living conditions different from those that prevailed in its country of origin was not its invention, as we said. We know that in the eighteenth century this conviction had even received the approval of naturalists, in some of the most prestigious scientific institutions. ${ }^{17}$ Should it be added that during these decades an early transformism or, at least, the French "environmentalist" ideas ${ }^{18}$ traced their path in French science-whose influence on scientific Belgium is well known ${ }^{19}$ - and somehow contributed to fuel this hope? Germany and Great Britain must also be credited with a certain influence on Belgian botany and horticulture at that time, as shown by the many contributions by German and British authors to the specialized Belgian press. However, this time acclimatization was going to be subject to the hindsight offered by a practice spanning several decades, to new "facts," and to the critical eye of emerging fields or practices, like phytogeography.

So, these are the debates, conflicts, doubts and convictions that we are going to discuss, by focusing firstly on one case: the history of the Belgian silk culture. Indeed, the fate of the latter seemed, we repeat, closely linked to the status of acclimatization, as a theory and a project. This little point in history will then allow us to assess this status within the Belgian agricultural and horticultural world in general.

Despite our title, the facts have forced us to set the start of our discussion in the last few years of the so-called "Dutch" period—from 1814 to 1830 — a period during which the future Belgium formed part of the Kingdom of the Netherlands. It closes with the Brussels International

\footnotetext{
${ }^{14}$ Morren, "Rapport sur les légumes," 266.

15 Kury, "André Thouin et la nature," 255-65.

16 Rémi Luglia, Des savants pour protéger la nature. La Société d'Acclimatation (1854-1960) (Rennes: Presses Universitaires de Rennes, 2015), 39 ff., 75 ff.

${ }_{17}$ Kury, "André Thouin et la nature," 260 ff.; Michael A. Osborne, Nature, the Exotic and the Science of French Colonialism (Bloomington and Indianapolis: Indiana University Press, 1994), 62-97.

18 Osborne, Nature, the Exotic, 63-70.

19 Geert Van Paemel, "Transformism and the question of species in Belgium before the introduction of darwinism," Tractrix 4 (1992): 13-37; Geert Van Paemel, "La révolution darwinienne," in Histoire des sciences en Belgique, 1815-2000, ed. Robert Halleux, Jan Vandersmissen, Andrée Despy-Meyer and Geert Van Paemel, 257-68 (Dexia Banque/La Renaissance du Livre: Bruxelles/Tournai, 2001).
} 
Horticultural Congress in the mid-1860s and a subsequent important contribution by one of the most prominent Belgian botanists of this time. During the congress, acclimatization will be the subject of debate, occasionally with somewhat irritated overtones, faithfully reflecting most of the questions and interpretations formulated in previous decades. We assume that this mobilization of the international scientific and horticultural elites around the theme of acclimatization in Brussels and especially the aforementioned article by Edouard Morren may constitute a milestone in the development of this idea in the country. But that was certainly not the end of it. Further study is needed to describe the fate of this theory, which some once described as a chimera-acclimatization, or whatever it is called—in post-1864 Belgium.

In this initial approach to the subject, we beachcombed a set of sources including the general press, the horticultural and agricultural press, archives from scientific institutions, publications by different experts, without forgetting government, educational and even lay publications. Supported by this documentary basis, we hoped to move between different qualities or types of rhetoric, knowledge and practice and, thus, to really get to grips with the issue, which can in fact be presented in very simple terms. In this young Belgium, proud of its horticulture and keen to revive an agriculture in crisis, did people think they could adapt an exotic plantpossibly tropical— to the demands of a climate other than its own and, if so, how?

\section{Producing Belgian silk: genesis and decay of an utopia}

What once was described as the Belgian sericultural utopia ${ }^{20}$ is rooted in the short period during which the future Belgium was part of the Kingdom of the Netherlands. It was the historian Henricus Van Den Eerenbeemt who shed light on the early days of this agro-industrial adventure. ${ }^{21}$ The works of Giovanni Federico have masterfully treated the history of sericulture in the world and in Europe, where the interest in silk production has a long history. ${ }^{22}$ Among the countries of temperate Europe (almost all of which abandoned it during the nineteenth century), ${ }^{23}$ the Netherlands showed an interest in this activity at the end of the eighteenth century. Revived in 1806, under the reign of Louis Napoléon, it was not developed due to doubts people already had about how well the mulberry tree could withstand the climate in these regions. However, during the reign of William I of Orange, the project re-emerged. ${ }^{24}$

\footnotetext{
${ }^{20}$ Diagre-Vanderpelen, The Botanic Garden, 45.

${ }^{21}$ Henricus F.J.M. van den Eerenbeemt, "Zijdeteelt in Nederland in de eerste helft der negentiende eeuw; perspectief tot een nieuwe bron van welvaart," in Ondernemende geschiedenis: 22 opstellen geschiedenis bij het afscheid van Mr. H. Van Riel als de Voorzitter van de Vereniging Het Nederlansch Economisch-Historisch Archief, ed. Harm Van Riel, 241-59 ('s-Gravenhage: M. Nijhoff, 1977).

22 Giovanni Federico, An economic history of the silk industry, 1830-1930 (Cambridge: Cambridge University Press, 2009), 7-42.

${ }^{23}$ Ibid., 13 ff.

${ }^{24}$ van den Eerenbeemt, "Zijdeteelt in Nederland," 241-43.
} 
In 1818, the press mentioned this plant on which the whole business depends: the mulberry tree, the Asian tree whose leaves the silkworm Bombyx mori L. feeds exclusively. ${ }^{25}$ People have long been convinced that the genus Morus L. holds the key to the entire European sericultural adventure. Moreover, when in 1826, the news of the creation of a new botanic garden in Brussels spread, and its brochure indicated that it would attempt to "acclimatize" several exotic plants $^{26}$ and to produce silk, an agronomist called Klynton ${ }^{27}$ rejoiced. Regarding the new institution, he made the following statements that were clearly indicative of the prevailing mindset: "We can only applaud the truly patriotic intentions of the horticultural society, which seeks to use our land to produce what we are forced to obtain from our neighbors." ${ }^{28}$ As we shall soon see, the main production was silk, in line with Klynton. ${ }^{29}$ Gaining independence by producing the country's own raw materials in order to supply an industry that had up to then depended on imports, this was the project whose mercantilist overtones were approved by the agronomist. In addition to the activities carried out by Brussels Botanic Garden, this took shape in 1826, when the Crown created a royal establishment for the breeding of silkworms and the cultivation of Morus in Meslin-l'Evêque (Hainaut, Belgium), a few dozen kilometers from Brussels. ${ }^{30}$ At the head of the company, which costed 40,000 guilders per year ${ }^{31}$ - a very large sum - was the Knight Bachelor Carlos de Beramendi, a former Spanish diplomat in Amsterdam looking for a new source of income. ${ }^{32}$

\footnotetext{
25 Anonymous, "De la culture Mûrier," Journal d'Agriculture, d'Economie rurale et des Manufactures du Royaume des Pays-Bas 6 (1818): 34-39, on 35.

26 Denis Diagre-Vanderpelen, "Le Jardin botanique de Bruxelles (1826-1912), miroir d'une jeune nation." (PhD diss., Université Libre de Bruxelles, 2006), 39.

27 E. Klynton defined himself as an engineer, physician, and naturalist. He was born in the USA and settled in Ghent around 1820, then moved to Saint-Josse-ten-Noode (Brussels) a few years later. We lose track of him after the 1830 revolution, perhaps due to his attachment to the House of Orange-Nassau. In the 1820s, he was a very outspoken critic of agriculture in the Netherlands and an enthusiastic promoter of silk culture in that country. In 1825, he confessed to 40 years of agricultural practice. See E. Klynton, "Correspondance," Journal d'Agriculture, d'Economie rural et des Manufactures des Pays-Bas 3 (1826): 55-9, on 55; Klynton, "Correspondance," 60; Henri Stephens and Edouard Jacquemyns, "Notice sur la culture du mûrier et l'éducation de vers à soie," Journal d'Agriculture, d'Economie rural et des Manufactures des Pays-Bas 7 (1828): 323-34, on 323-25; Anonymous, "Mûriers- Vers à soie," Journal d'Agriculture, d'Economie rural et des Manufactures des Pays-Bas 11 (1830): 158-64, on 158; E. Klynton, Manuel sur la culture du Mûrier propre à l'éducation de la chenille à soie (Bruxelles: P. Vleeminckx, 1830), 15, 50, 55-6; E. Klynton, Première suite à l'Appel au patriotisme des propriétaires, agriculteurs et cultivateurs des Pays-Bas (Gand: Imprimerie de J.-N. Houdin, July 1828), 16.

${ }^{28}$ Klynton, "Correspondance," 61.

${ }^{29}$ Ibid., 58-61.

${ }^{30}$ van den Eerenbeemt, "Zijdeteelt in Nederland," 245.

31 Alberto Andres Aguirre, “Carlos Beramendi en Aragon y Cataluña (1792-1793). Un viaje en el filo de la Modernidad.” (PhD diss., Universidad de Alicante, 2016), 89.

32 van den Eerenbeemt, "Zijdeteelt in Nederland," 244.
} 
Some years earlier, he had produced silk on a small scale, on his estate. It is said that he had offered it to the Queen of the Netherlands and thus rekindled interest in silk culture within the kingdom..$^{33}$

Undoubtedly of greater importance in determining the outcome of this matter was the commercial power struggle that was then taking place between the Netherlands and France. The tariffs charged on the importation of products from the Netherlands in this country were undoubtedly connected with the revival of interest in silk culture. In fact, as retaliatory measures, the small kingdom had decided to raise taxes on various products—including silkfrom its large neighbor, thereby increasing the prices at home. This is where Beramendi's expertise was successful, we believe.

In any case, King William of Orange decided to encourage the production of national silk. ${ }^{34}$ This renewed interest was noticeable because, between 1826 and the Belgian revolution for independence (1830), the press in the Kingdom of the Netherlands took up the subject with renewed enthusiasm. These articles already mentioned most of the topics, fears and preventive measures that would punctuate the debates during the following decades. Moreover, the debate became polarized, and quite militant opinions were expressed.

As an example, between 1827 and 1830, when the model establishment of Meslin-l'Evêque had not yet been established, an agricultural newspaper published a series of texts devoted to the cultivation of Morus and the breeding of silkworms. One of them, without supporting the impossibility of this activity, in fact pointed out several difficulties that it could be faced with. First it claimed that the climate would have an impact on the quality of the leaves, and therefore on the quality of the silk. In addition, it explained that the nature of the soil and the exposure of the land were important, because young mulberry trees were supposedly unable to withstand frost. Finally, it stated that all mulberry trees (species or "varieties") were not suitable for all stages of silkworm breeding. This meant that different types had to be planted. The author concluded that mulberry trees were not much more demanding than fruit trees, and that the government would soon encourage the cultivation of the former. However, his words remained full of reservations. ${ }^{35}$

The point of view expressed in the same journal a few months later was very different. "Those in our country who are going to devote themselves to this new type of industry should have

\footnotetext{
33 Aguirre, "Carlos Beramendi," 85.

${ }^{34}$ van den Eerenbeemt, "Zijdeteelt in Nederland," 244-45.

35 Anonymous [a Belgian nurseryman], "Notice sur la culture du mûrier pour la nourriture du vers à soie, adressée à l'éditeur du journal d'agriculture et des manufactures des Pays-Bas; par un pépiniériste de la Belgique," Journal d'Agriculture, d'Economie rurale et des Manufactures du Royaume des Pays-Bas, 2nd series, 6 (1827): 210-18.
} 
high hopes!," they exclaimed. Reassuring, the author added that "All the books on mulberry trees indicate a long list of precautions that need to be taken when cultivating them; in my experience, . . . about three quarters of them are superfluous." ${ }^{36}$ Alleged sensitivities to soil type or frost were dismissed, allowing the author to suggest that most regions of the country were suitable for Morus. The author's conclusion was not surprising: "So, after establishing that the mulberry tree, essential source of food for the caterpillars that give us this precious thread, can prosper in Belgium, we should be confident that a government whose only concern is to increase national wealth will encourage a new industry, which in a few years will probably equal, if not surpass, our most productive and profitable manufacturing industries." ${ }^{37}$

The agronomist Klynton, once again, and the Messager des Sciences et des Arts, journal of the Société d'Agriculture et de Botanique de Gand (Agricultural and Botanical Society of Ghent), were also at the forefront of those commenting on the national silk culture project. In 1830 alone, the journal published three articles on silkworm and mulberry tree cultivation, or on the creation of associations focusing on these objectives. ${ }^{38}$ Klynton, meanwhile, among other works and texts, even published a Manuel sur la culture du mûrier (Manual on mulberry cultivation), an authentic eulogy to a tree de la bénédiction de Dieu dont les feuilles produisent de l'or (blessed by God whose leaves produce gold) ${ }^{39}$ and a still faltering industry, which he defended tooth and nail. To achieve his goal, he resorted to a fictitious dialogue between an agronomist and a group of farmers who were stuck in harmful routines. These are stereotypes, in the agricultural press of that time. ${ }^{40}$ Here, the man of science and reason berated the defiance of foreign plants - whilst everyone knew, he recalled, that the potato, originally from the New World, had become indispensable ${ }^{41}$ - , refuted the claimed farming difficulties linked to the soil and climate, mocked the routine mind set of the "ignorant cowards of the good old days," 42

\footnotetext{
${ }^{36}$ Anonymous, "Vers à soie et mûriers," Journal d'Agriculture, d'Economie rurale et des Manufactures du Royaume des Pays-Bas, 2nd series, 6 (1827): 274.

37 Anonymous, "Vers à soie et mûriers," 277-78.

38 Anonymous, "Société érigée à Gand pour la propagation du mûrier et l'éducation des Vers-à-soie, dans le royaume des Pays-Bas," Le Messager des Sciences et des Arts, Collection publiée par la Société Royale des Beaux-Arts et des Lettres, et par the Société Royale d'Agriculture et de Botanique de Gand (1829-1830), 306-07; Anonymous, "Culture du Mûrier blanc," Le Messager des Sciences et des Arts, Collection publiée par la Société Royale des Beaux-Arts et des Lettres, et par the Société Royale d'Agriculture et de Botanique de Gand (1830), 315; Alexandre Rodenbach, "Fabrique de soie, culture du mûrier," Le Messager des Sciences et des Arts, Collection publiée par la Société Royale des Beaux-Arts et des Lettres, et par the Société Royale d'Agriculture et de Botanique de Gand (1830), $329 \mathrm{ff}$.

39 Klynton, Manuel, 5.

${ }^{40}$ Vanhaute and Van Molle, "Het einde van de overlevingslandbouw," 17-33; Chloé Gaboriaux, "Entre innovations agronomiques et pratiques paysannes. La figure de l'agriculteur pratique' au 19e siècle," in Sciences, chercheurs et agriculture. Pour une histoire de la recherche agronomique, ed. Christophe Bonneuil, Gilles Denis and Jean-Louis Mayaux, 45-60 (Versailles/Paris: Quae/L'Harmattan, 2008), 46-9.

${ }^{41}$ Klynton, Manuel, 13-4.

42 Ibid., 14.
} 
dissipated the fear of an uncertain profit ... and affirmed the need to plant millions of mulberry trees, ${ }^{43}$ throughout the country. ${ }^{44}$ This is the reply to the rhetoric that refuted the possibility of ensuring the prosperity of the white mulberry tree, the best species for silk production: "nothing is easier because this tree is propagated by seeds, cuttings and air layering, sown in spring directly in the ground, in a properly exposed location." ${ }^{45}$

Beyond the cultural issue, these lines also reveal the threat that the rolling out of Dutch sericulture avoided and no doubt explain why it was promoted by some. "Indeed, doesn't the national cotton industry depend on an imported raw material," recalled Klynton. And what would happen if this raw material no longer arrived or if the international competition made its processing into the finished product unprofitable? ${ }^{46}$

In the Netherlands, nothing indicates better the prevailing mind set of the social elites in the silk culture sector than the annals of the Morus and Bombyx Society, an association created in Ghent in 1829. Its goal was to propagate and perfect the cultivation of the white mulberry tree and the breeding of silkworms. ${ }^{47}$ However, one of its members mentioned "the constant care" that his 40,000 white mulberry trees plants required during the winter. Even though he suggested the creation of a joint-stock company dedicated to white mulberry tree farming, he added that there was still a risk, linked to a fundamental doubt. It lies in the following words: "Once the Morus and Bombyx Society thinks that the white mulberry tree can grow in Belgium ${ }^{48}$ and produce almost as many leaves as those grown in France, it will be time to boost an industry that interests the entire population of the Kingdom." ${ }^{49}$

\section{The Belgian sericultural utopia: take-off}

The 1830 revolution, which gave rise to the creation of Belgium through its separation from the Netherlands, led to a serious economic crisis in the fledgling country. ${ }^{50}$ The loss of the Dutch market and of its colonies, as well as the closure of the River Scheldt, essential for trade,

\footnotetext{
43 Ibid., 63.

${ }^{44}$ Ibid., $15-7$.

45 Ibid., 56.

${ }^{46}$ Ibid., 37, 60-1.

${ }^{4}$ Annales de la Société pour la propagation du Mûrier et l'Education des Vers à soie dans le Royaume des Pays-Bas, sous la devise: Morus et Bombyx, érigée à Gand, le 1er août 1829, 1 (1830): 1.

${ }^{48}$ Indeed, the term Belgium was used before the independence revolution. Whilst it is not always easy to know which geographical area it referred to, at the time when this text was written, it must have been the southern provinces of the Kingdom of the Netherlands. See Sébastien Dubois, Linvention de la Belgique. Genèse d'un Etat-Nation, 1648-1830 (Bruxelles: Editions Racine, 2005), 143-54.

49 Annales de la Société pour la propagation du Mûrier, 25.

50 Witte, "La construction," $125 \mathrm{ff}$.
} 
thus had a major impact on the decisions the legislative Chambers were led to take. They had to develop industry and transport, spend public money in the areas of greatest need and minimize public expenditure in the areas in which returns were not assured, etc. ${ }^{51}$ The case of Brussels Botanic Garden, whose contribution to society seemed far from being proven, was an example of this. Its subsidies were threatened for several years, and it was ordered to prove that it carried out agricultural or industrial tests that could enrich the country. ${ }^{52}$ This is, no doubt, the reason why it soon started to produce cocoons. ${ }^{53}$ The Meslin-l'Evêque silk culture facility experienced a similar situation, since, whilst Belgium took over the site in 1831, that year the large subsidies granted by the previous regime dropped to one tenth ${ }^{54}$ and later to a mere one twentieth of the original amount, according to certain sources. ${ }^{55}$ However, the alarm was short-lived because, in 1832, the Belgian Government committed to taking bolder measures to encourage the national silk culture: the granting of bonuses and awards to the most zealous Morus farmers and the most efficient silkworm breeders, but also the free distribution of thousands of mulberry tree seedlings. ${ }^{56}$ The following year, it even supported a national exhibition in Brussels devoted to this activity. ${ }^{57}$ It should be noted that the encouragement given to this industry was not a unique occurrence, as the Belgian Government also reserved funds to finance tests on some potentially useful, and somewhat "prestigious," exotic plants. ${ }^{58}$

In January 1832, at the Meslin-l'Evêque facility, Charles de Mévius replaced Carlos Beramendi. De Mévius had travelled throughout southern Europe at his own expense and had studied local productions, including silk, above all in Italy. It was said that the establishment of this activity became a mission for him. ${ }^{59}$ He soon obtained 24 hectares of land from the State on which to set up a mulberry tree nursery in Forest $(1834),{ }^{60}$ a commune that now forms part

${ }^{51}$ Ibid., $135 \mathrm{ff}$.

52 Diagre-Vanderpelen, The Botanic Garden, 44-5.

53 Ibid., 45.

${ }^{54}$ Maarten Van Dijck, De wetenschap van de wetgever. De klassieke politieke economie en het Belgische landbouwbeleid, 1830-1884 (Leuven: Universitaire Pers Leuven, 2008), 122.

55 Philippe Vandermaelen and François Meisser, Dictionnaire géographique de la Province de Hainaut (Bruxelles: Etablissement géographique, 1833), 237.

${ }^{56}$ Pasinomie ou Collection complète des lois, Décrets, Arrêtés et Règlements généraux qui peuvent être invoqués en Belgique (Bruxelles: Bruylant, 1831-1832), no. 253.

${ }^{57}$ Van Dijck, De wetenschap, 129.

${ }^{58}$ Until the middle of the century, this outline of agricultural policy, drawn up by the national elites, essentially targeted "prestige" crops such as vines and, of course, silk. See Van Dijck, De wetenschap, 119 ff.; Vanhaute and Van Molle, "Het einde van de overlevingslandbouw," 29-33.

59 Charles Morren, "A la mémoire de Charles-Joseph Baron de Mévius," Journal d'agriculture pratique, d'économie forestière, d'économie rurale et d'éducation des animaux domestiques du Royaume de Belgique 7 (1854): vi.

${ }^{60}$ Ibid., vii. We shall note that the establishment was for a long time deemed to have been built in the commune of Uccle. In fact, it was located in the commune of Forest. See Jean-Marie Pierrard, "Lélevage du ver à soie et la culture du mûrier à Forest après 1830,” Ucclensia 132 (1990): 4-10. 
of Brussels. The leaves that were picked there were transported daily to Meslin-l'Evêque, to feed the caterpillars in the existing magnanery (silkworm nursery). According to some sources, the mulberry trees in this facility, which was badly designed and poorly planted, were not productive enough. ${ }^{61}$ However, when de Mévius, with the blessing of the public authorities, took control of the Belgian State sericulture, concerned voices were again raised regarding the future of this activity in the country if the Government did not provide it with considerable support.

For this inhabitant of Verviers, the stakes were high: in his opinion, and in that of many other people, to ensure its future and become an industrial nation, independent Belgium had to escape from the "tax" ${ }^{\prime 2}$ that it paid to other nations for the supply of raw materials. According to him, lame results in sericulture would discredit a business that, well-conducted, with the financial support of the State, could encourage lay people to get involved. In a nutshell, this adventure with an agricultural and industrial character - the two pillars of future success for the country, according to the author of this plea —offered too many advantages to be dropped off. Among these advantages, he mentioned the unproductive wastelands planted with mulberry trees and thousands of families working and becoming prosperous ${ }^{163}$ This was of great importance in a country that was experiencing a growing proletarianization of its agricultural populations, whose survival depended on complementary proto-industrial activity. ${ }^{64}$

And yet, a decade later, after distributing hundreds of thousands of Morus trees free of charge, ${ }^{65}$ as well as millions of Bombyx eggs, ${ }^{66}$ the Belgian Government, after concluding, in 1833, that the quality of Belgian silk was perfect ${ }^{67}$ and after an official commission had carried out a national survey, which showed that the Belgian silk industry was doing very well, ${ }^{68}$ pulled

${ }^{61}$ See, notably, Anonymous, "Correspondance. Bruxelles, 30 Novembre 1832," Journal d'Agriculture, d'Economie forestière, d'Economie rurale et des Manufactures des Pays-Bas, 3rd series, 4 (1832): 339-44.

${ }^{62}$ Jean-François Constant, "De la nécessité de répandre en Belgique l'art d'élever les vers à soie et d'encourager les fabriques de soieries," Journal d'Agriculture, d'Economie forestière, d'Economie rurale et des Manufactures des Pays-Bas, 3rd series, 4 (1832): 209.

63 Ibid., 193-209.

${ }^{64}$ Vanhaute and Van Molle, Het einde van de overlevingslandbouw, 24-33.

65 The distribution of these trees was decided in 1832. See Anonymous, "Essai statistique sur les résultats obtenus de l'introduction de la culture du mûrier et de l'éducation du ver à soie en Belgique," Revue Universelle. Bibliothèque de l'Homme du Monde et de l'Homme politique au 19 e siècle, Première année, VI (1833): 231-38; Pasinomie. Collection complète des Lois, no. 253.

66 We see, for example, the establishment of Meslin-l'Evêque sent its Bombyx eggs to Brussels Botanic Garden in 1835, 1836 and 1837. See the Letters from Ch. De Mévius to the Société royale d'Horticulture, 25 September 1835, 16 May 1836 and 25 April 1837, Archives de la Société Royale d'Horticulture, no. 254, Botanic Garden Meise.

${ }^{67}$ Anonymous, "Projet de loi relatif à l'aliénation des établissements d'Uccle et de Meslin-l'Evêque. Séance du 10 mars 1840. Rapport fait par Monsieur Zoude," Moniteur Belge, 74 (1840): n.p.

${ }^{68}$ Anonymous, "Projet de loi relatif à l'aliénation." 
out of the facilities in Meslin-l'Evêque and Forest. This maneuver began in $1839,{ }^{69}$ but would not finish until two years later. Behind this withdrawal was Charles de Mévius himself, tired of seeing each year how the financial resources of his establishments were threatened by the parliamentarians who were rather hostile during voting on State budgets. Apparently, he proposed to the Minister of the Interior to take back the Forest establishment, whilst assuring, at his own expense, the continuity and development of its activities. ${ }^{70} \mathrm{~A}$ commission was to study his proposal, and it was finally discussed in the Chamber of Deputies and in the Senate in 1841 .

What we should retain from these long debates full of contradictory information is that the Ministers of the Interior, who were successively in charge of this project to dispose of or rent out the two sericultural institutions (in Meslin-l'Evêque and Forest/Uccle), did not aim to cease all State support to the silk industry, but rather to prolong it whilst, at the same time, reducing the burden on the national budget. Aware too that both the Chamber and the Senate were systematically reluctant when it came to voting on the sums allocated to this activity, they envisaged selling or renting the two establishments at a low price to Charles de Mévius or, possibly, to another competent person. However, several conditions were to prevent the prolongation of the tests that had been carried out there for 10 years: the obligation to build, at the buyer's or tenant's expense, all the elements of a magnanery in Forest because, at this stage, only mulberry leaves were being produced there; the obligation to divulge procedures and results in order to encourage the emergence of a private sericultural sector; and the obligation to continue testing during the period required for the formulation of a definitive conclusion on the viability of the Belgian sericultural industry, among other things.

So, this was carried out, after bitter debates the details of which do not need to be provided. So, Charles de Mévius rented the vast piece of land in Forest and made it into a private model establishment for growing mulberry trees and producing silk. ${ }^{71}$ All this was in line with the then prevailing ideology of cautious and sporadic State interventionism in agriculture. ${ }^{72}$ De Mévius died in 1852, and the establishment survived him, until the mid-1860s apparently, although it is not clear in what kind of condition. It should be noted that, since the early 1840 s, a silkworm disease had spread, turning this activity, which the climate in northern

${ }^{69}$ Anonymous, "Présentation par M. le Ministre de l'Intérieur et des Affaires étrangères de deux projets de lois tendant à autoriser le Gouvernement à vendre les établissements sétiferes de Meslin-l'Evêque et Uccle. Séance du 18 mai 1839," Moniteur Belge, 138 (1839): n.p.

${ }^{70}$ Anonymous, "Discussion du projet de loi relative à l'aliénation des Établissements modèles d'Uccle et de Meslin-l'Evêque, pour la culture du mûrier et l'éducation du ver à soie," Moniteur Belge, 15 (1841): n.p.

${ }^{71}$ A law of 16/3/1841 allows the Forest nursery to be rented to Charles de Mévius. See Auguste Ronnberg, Traité de la culture du Mûrier et de l'éducation des vers à soie en Belgique, Résumé des meilleurs auteurs français et italiens (Bruxelles: Bibliothèque rurale instituée par le Gouvernement, 1853), 152.

${ }^{72}$ Vanhaute and Van Molle, "Het einde van de overlevingslandbouw," 24-33. 
Europe was already making difficult, even more uncertain. This might have been the final cause for the end of the Belgian silkworm utopia. ${ }^{73}$

Whatever the case, some of the words that had resonated in the legislative chambers warrant attention. Because, indeed, the desire to prolong testing was rooted in a nagging doubt, criticized a thousand times by some people, for being ridiculous, or even for not conforming with the facts or for being pusillanimous.... An inextinguishable doubt.

\section{The success of the white mulberry tree in Belgium still in question}

At the parliamentary session of January 14, 1841, the Minister of the Interior was to utter these bitter words, tinged with irritation: "As for what we have been told about the impossibility of acclimatizing the mulberry tree in Belgium, I would like us to reply about what is happening in our neighbors' country, in a country north of Belgium. Why is this crop more impossible in Belgium than in Prussia, where people find it so possible that it is spreading more and more every day!"’44

In the Senate, a few weeks later, the liberal Dumon-Dumortier, introducing a criterion of profitability, qualified the issue a little, without modifying the substance of the question: "We have carried out tests; the mulberry trees grow well, the silkworms are being bred there, but by fictitious means we can still have any results we want, we could grow coffee and indigo plants in greenhouses; but would this crop be advantageous for Belgium?" 75 For his colleague, Baron de Stassart, things were admittedly much clearer: all efforts were in vain, acclimatization was impossible. In a liberal creed, he stated that: "Each country has its own culture and focuses on the industries that favor it most. We must not only try to be self-sufficient, but also try to create a trade of exchanges. People wanted to acclimatize vines; I think that as long as there are gourmets in Belgium, people won't be too keen on local wines." ${ }^{76}$

In fact, the doubt presented to the Chamber, a doubt that we mentioned, and which justified the transfer of the responsibility for sericultural tests to de Mévius, was to be repeated by the

\footnotetext{
${ }^{73}$ Federico, An economic history, 4, 38-9.

${ }^{74}$ Anonymous, "Discussion du projet de loi relative à l'aliénation des Établissements modèles d'Uccle et de Meslin-l'Evêque, pour la culture du mûrier et l'éducation du ver à soie," Moniteur Belge, 15 (1841): n.p.

75 Anonymous, "Discussion du projet de loi relative à l'aliénation des Établissements modèles d'Uccle et de Meslin-l'Evêque, pour la culture du mûrier et l'éducation du ver à soie," Moniteur Belge, 61 (1841): n.p.

${ }^{76}$ Ibid., n.p.
} 
Minister thus, to the Senate: "[the Government wants to know] once and for all if we can acclimatize on our land ... the white mulberry tree, whose leaves are eaten by the silkworms." ${ }^{\prime 7}$

Twelve years later, it appears that the questions were resolved. In fact, as if to prolong the work that the recent death of Charles de Mévius appeared to threaten, the Belgian Government made a symbolic gesture: the publication of propaganda in the form of a long book entirely devoted to silk culture and its viability in Belgium. It contained the most reassuring words on the cultivation of mulberry trees in the country and on the future of an industry that the Minister of the Interior, after two decades of commitment, still clung on to ${ }^{78} \ldots$ in vain. At any event, these pages prove that the Belgian sericultural adventure depended on acclimatization, the very possibility of acclimatization (Figure 1).

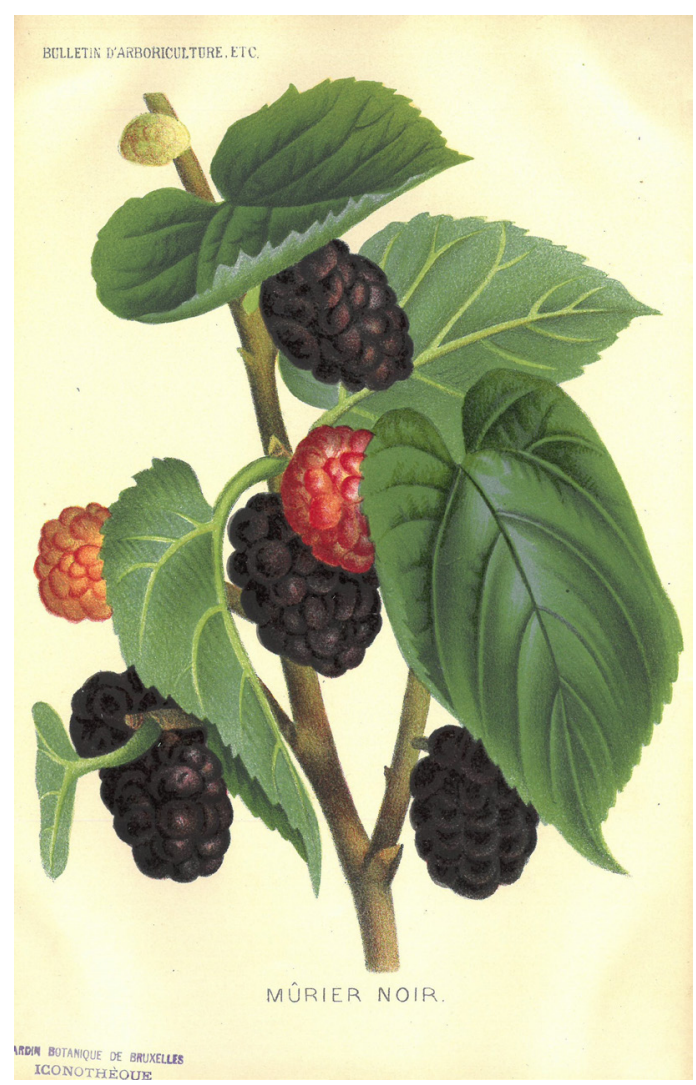

Figure 1. Often seen as a possible substitute for Morus alba, the more frost-resistant Morus nigra ended up as an ornamental plant in the nineteenth century Belgian gardens. Source: Meise Botanic Garden, Picture Library, undated. Property of the Belgian State, on permanent loan to the Botanic Garden Meise.

\footnotetext{
77 Ibid.

${ }^{78}$ Ronnberg, Traité de la culture du Mûrier, $13 \mathrm{ff}$.
} 


\section{The debate on plant acclimatization in Belgium}

The words of the famous English botanist, John Lindley, reported by an anonymous author in the Journal d'Horticulture pratique de la Belgique, in 1849, painted the picture of an astonishingly clear scenario:

For a long time we have seen . . . a constant truth, whilst plants cannot modify the climate; the constitution of plants can be modified by the climate; all the procedures we used to try to obtain this effect were called acclimatization. This opinion is expressed in a large number of books, and there is not one village in which hardheaded individuals do not accept this as an article of faith. However, this is exactly the opposite of the truth. We can reverse the proposal and say that the constitution of plants cannot be modified by the climate, but that the climate can be modified in order to make it suit the temperament of plants. The importance of this truth is as obvious as the world's lack of willingness to believe it. $^{79}$

So, would acclimatization, an extremely practical question - at first sight, in any case-no longer be questioned at that time, except by village minds struck, Lindley appeared to think, by some kind of rural backwardness? Can we believe this, when we know that five years after the publication of these lines in Belgium, France was to set up an Acclimatization Society-a society with an undeniable international aura — presided over by Isidore Geoffroy Saint-Hilaire, one of the leading scientists of his day? ${ }^{80}$

More probably, this paradox illustrated the philosophical breach between, on the one hand, an Anglo-Saxon science tinged with natural theology, with the idea of an almost perfect creation, thus only slightly malleable, and, on the other hand, a French science, more prone to believe in a greater flexibility of life forms, in human hands or even spontaneous. ${ }^{81}$ However, whilst the Belgian sericultural adventure has clearly proven that the country did not ignore this debate, we would like to know how, when a national scientific arena was being constituted, ${ }^{82}$ subject to intellectual influences of neighboring countries_Lindley's was not the only one, as we shall see-, the important question of acclimatization was raised.

\footnotetext{
79 Anonymous, "Des effets de la température du sol sur la vegetation," Journal d'Horticulture pratique de la Belgique 6 (1849): 362-63.

${ }^{80}$ Luglia, Des savants 39 ff.; Osborne, Nature, the Exotic, 62-97; Santiago Aragon, "Le rayonnement international de la Société zoologique d'acclimatation: Participation de l'Espagne entre 1854 et 1861," Revue d'Histoire des Sciences 58, no. 1 (2005): 169-206.

${ }^{81}$ Michael A. Osborne, "Acclimatizing the World: A History of the Paradigmatic Colonial Science," Osiris 15 (2000): 135-51, on 150.

82 Robert Halleux, "La marche des idées," in Histoire des sciences en Belgique, 1815-2000, ed. Robert Halleux, Jan Vandersmissen, Andrée Despy-Meyer and Geert Van Paemel, 17-36 (Dexia Banque/La Renaissance du Livre: Bruxelles/Tournai, 2001).
} 
Which hopes, which convictions, which theories and which practical experiences influenced Belgium? Which thought was it going to be the heir to or to pass on, and in which media?

\section{An original lexical problem}

First, we should point out that, whilst the French term acclimatation (acclimatization) appeared at the very end of the Eighteenth century, the creation of the project to "accustom plants gradually" to a climate other than their own native one, seems to go back to the Encyclopédie (1751), written by Louis Daubenton. ${ }^{83}$ Nevertheless, the use of this word was to reveal a certain number of nuances that would vary in accordance with the time, place and even the culture. ${ }^{84}$ The historical sources reveal that there is no doubt about the existence of this situation, of a "problem" of vocabulary. Researchers today come up against it constantly, just as agronomists, farmers, and lay persons no doubt did in the nineteenth century.

In fact, the imprecise use of the term acclimatation soon led to irritated reactions. In France, Brisseau de Mirbel, chair in culture at the Muséum de Paris, ${ }^{85}$ pointed it out and, in 1834, called for clarification. ${ }^{86}$ L'Horticulteur Belge, at the same time, illustrated this situation where acclimater (acclimatize) was considered a synonym of naturaliser (naturalize), in several works, which clearly supported the fact that the process in question could only be envisaged in cases where a plant was introduced in a place with a climate similar to that of its country of origin. ${ }^{87}$ Acclimater, in the latter interpretation — which prevailed at that time "in the British sphere" did not mean to force a plant to adapt to a climate other than the one in its place of origin, but simply to introduce it successfully to a land where it was not known, and where the living conditions were similar to those of its origins. The German botanist, Johann Heinrich Link, one of the first in our Belgian sources, was also concerned about this lexical vagueness and proposed a definition aimed at dispelling a rumor that has been doing the rounds for a long

${ }^{83}$ Jean-Marc Drouin, "Le 'moral' des plantes: introductions, hybridations et monstruosités végétales au XIXe siècle," Journal d'Agriculture traditionnelle et de botanique appliquée 37, no.1 (1995): 7-8.

${ }^{84}$ Osborne, "Acclimatizing the World," 137.

${ }^{85}$ Philippe Jaussaud and Edouard-Raoul Brygoo, Du jardin au Muséum en 516 biographies (Paris: Muséum national d'Histoire naturelle, 2004), 384-86.

86 Drouin, "Le 'moral' des plantes," 8.

87 Anonymous, "Rapport fait à la Société d'Horticulture de Paris, au nom d'une commission spéciale, composée de MM. Le comte de Murinais, président; le vicomte Debonnaire de Gif, Mérat, Jacques, l'abbé Berlèse, Poiteau et Loiseleur-Deslongchamps, rapporteur sur les cultures qui pourraient être utiles à la colonie d'Alger," Horticulteur Belge 1 (1833-1834): 138-58; Anonymous, "Anniversaire de Linné," Horticulteur Belge 1 (1833-1834): 59-60.

${ }^{88}$ Osborne, "Acclimatizing the World," 137. 
time: "To acclimatize, in the true sense of the word, means to accustom an organized being to a climate that, on its own, it cannot withstand." 89

The confusion remained, since in the elitist context of the international horticultural congress in Brussels, almost thirty years later, it required the same defining reframing by Jules Planchon, immediately followed by several of his colleagues. ${ }^{90} \mathrm{~A}$ clarification that, very symptomatically moreover, opened debates on the first topic discussed at this meeting: "Acclimatization, naturalization, domestication of plants." We shall come back to this in due course. It is worth noting, in any case, that the definition proposed by Planchon, which is also the one put forward by Link and accepted by most of the congress participants whose interventions we retain, was nothing new. In fact, it had been suggested previously by two of the great names in botany, Augustin, and Alphonse de Candolle, in 1832 and 1855 respectively. ${ }^{91}$ So, why did they have to come back to this issue, then?

One of the probable causes of this situation may be that the reported imprecision existed, for a long time, in influential writings, such as that of the famous botanist, André Thouin, a horticultural point of reference of his day. ${ }^{92}$ Moreover, it was Thouin that Brisseau de Mirbel was referring to in 1834. For the former head gardener of the Jardin du Roi (King's Garden), later to become chair of culture at the Muséum de Paris (Museum of Paris), ${ }^{93}$ the undifferentiated use of the French words' naturalisation and acclimatation could perhaps be explained by the fact that he did not feel there was a need for two concepts. Indeed, although he often appeared to indicate the contrary, ${ }^{94}$ Thouin was, like Daubenton and other naturalists forged in the crucible of Eighteenth century France, credited with a form of conviction that it was possible to adapt all plants to all climates, given enough time. ${ }^{95}$ Moreover, did the first regulations of

${ }_{89}$ Anonymous, "De l'acclimatation des végétaux; par M. Link, conseiller intime et professeur de botanique à Berlin," Horticulteur Belge 4 (1837): 337.

${ }^{90}$ For Planchon, acclimatization suggested "that a plant transported from one country to another could change temperament and progressively get used to the new conditions it was subjected to." See Anonymous, Bulletin du Congrès International d'Horticulture qui a été réuni les 24-26 April 1864 (Gand: C. Annoot-Braeckman, 1864), $67 \mathrm{ff}$.

${ }^{91}$ Augustin-Pyrame de Candolle, Physiologie végétale, ou exposition des forces et des fonctions vitales des végétaux, pour servir de suite à l'organographie végétale et d'introduction à la botanique géographique et agricole (Paris: Béchet jeune, 3, 1832), 1126-127; Alphonse de Candolle made a clear distinction between "naturalisation" and "acclimatisation," the latter being a farmer's "pipe dream." See Alphonse de Candolle, Géographie botanique raisonnée ou exposition des faits, principaux et des loi concernant la distribution géographie des plantes de l'époque actuelle (Paris-Genève: Victor Masson, 2, 1855), 1086.

${ }_{92}$ Lorelai Kury, Histoire naturelle et voyages scientifiques (1780-1830) (Paris: L'Harmattan, 2001), 22021; Yvonne Letouzey, Le Jardin des Plantes à la croisée des chemins avec André Thouin, 1747-1824 (Paris: Muséum national d'Histoire naturelle, 1989), 519-55.

${ }_{93}$ Jaussaud and Brygoo, Du jardin au Muséum, 491-93.

${ }^{4}$ André Thouin, Cours de culture et de naturalisation des végétaux (Paris: Huzard-Deterville, 3, 1827), $387 \mathrm{ff}$., in particular.

${ }^{95}$ Kury, "André Thouin et la nature," 263- 65; Spary, Le jardin d'Utopie, 160 ff. 
the Muséum de Paris not mention a duration of one hundred years before obtaining certain results in this area? ${ }^{36}$ Acclimatize and naturalize, in this respect, would appear to designate a single operation that faith in the "infinite perfectibility" ${ }^{97}$ of living beings made possible. Therefore, any success will come from acclimatization — which Thouin and others were to give this name-, and any failure would simply be an emerging success. ${ }^{98}$

An academic from Belgium, Charles Morren, who will be discussed at length, illustrates this foggy situation very well when he evokes, still in 1855, the costly and unsuccessful attempts at naturalization carried out in his country. ${ }^{99}$ The need to dissociate the terms, was, however, to arise. So, the very same year, Alphonse de Candolle also noted that, according to him, the people were misled who had given the name acclimatization to a phenomenon that was simply naturalization, the successful introduction of a plant that was spontaneously capable of this, then. ${ }^{100}$ In fact, continuing to exist in the literature and in people's minds, we believe that these two words gave rise to real confusion, by progressively taking on different meanings in favour of a scientific context itself constantly evolving. Perhaps the emergence of botanical geography and its questions, ${ }^{101}$ with what this discipline presupposes as being the most firmly entrenched in landscapes and plant associations, played a significant role in the formation of these lexical blurs. ${ }^{102}$ In any case, confusion arose from an old synonym: naturalization and acclimatization remained, for some people, synonyms that meant "to adapt" a plant to living conditions completely different from those in its place of origin, which we would readily call, as many botanists did at that time moreover, acclimatization sensu stricto. It is possible that this confusion gave rise to the hope, apparently widespread, of progressively accustoming exoticeven tropical-plants to the living conditions of the Belgian countryside and gardens. The persistence of a hope that the topic discussed by the congress participants in 1864, and many other texts, also directly indicated.

\section{Put in a wider context}

Whilst the pages of the Belgian horticultural press in the years directly following the independence revolution showed that the acclimatization of exotic plants warranted debate,

\footnotetext{
${ }^{96}$ Kury, "André Thouin et la nature," 261.

97 Spary, Le jardin d'Utopie, 161.

98 Kury, "André Thouin et la nature," 265.

${ }_{99}$ Charles Morren, "Théorie des harmonies entre les feuilles et la forme générale des arbres et révélation par les feuilles de la culture rationnelle des végétaux arborescents," Belgique Horticole 5 (1855): 116.

100 de Candolle, Géographie botanique, $798 \mathrm{ff}$.

${ }^{101}$ Drouin, "Le 'moral' des plantes," 8-9.

102 Bourguet, "La collecte du monde," 195.
} 
the lexical question also showed that it was an older cultural and scientific heritage, and the product of a context that went beyond the framework of the Netherlands.

From the very outset, we should point out that the regions that today make up Belgium, formerly part of the Habsburg Empire, then aggregated to revolutionary and imperial France and, finally, the Kingdom of the Netherlands, did not discover exotic, or even, tropical plants in 1830 . People were very aware of what their diet owed to the potato, ${ }^{103}$ notably, and the art of gardening had for a long time been including species that sometimes came from countries very far away. ${ }^{104}$ To those who doubted the possible success of Morus in Belgium and the supply of exotic flowers to Europe, various nineteenth century authors reiterated something that has been a cliché since the middle of the eighteenth century, at least: ${ }^{105}$ what the general public owed to the Andean tubercle and to wheat, which was believed to originate from the Middle East. ${ }^{106}$

And nevertheless, the farmers' mistrust of any new and "foreign" plant was ridiculed a thousand times in our sources, and readily treated as a manifestation of a fearful and mundane mind set. ${ }^{107}$ Apparently, far from finding inspiration, as it arrived, in scientific thought or in the fear of a major replacement of local flora by exotic plants, ${ }^{108}$ Pierre Joigneaux, French politician and agronomist who took refuge in Belgium during the Second Empire, referred to these mistrustful farmers as "marmottes de la création" (a French expression equivalent to "the sloths of Creation"). ${ }^{109}$ As for knowing the real importance and depth of the phenomenon, that is another matter. Indeed, numerous agricultural works of the day took on a militant approach and were accompanied by a disparaging rhetoric that demanded a caricatured enemy: the conservative individual, the coward, etc. It seems certain, in any case, that the passion for novelty was not so much to be found in a peasantry that lived on the razor's edge at the time, as in the elites who sought to enhance their gardens with exotic plants or to launch new industries based on foreign plants. ${ }^{110}$

\footnotetext{
103 Vanhaute and Van Molle, "Het einde van de overlevingslandbouw," 18-29.

${ }^{104}$ Rene De Herdt and Patricia De Corte, Fine fleur. Floralies gantoises et art floral (Tielt: Lannoo, 2005), $10-20$.

105 Drouin, "Le 'moral' des plantes," 6.

106 Klynton, Manuel, iv; Anonymous, Les Fêtes de Septembre illustrées ou Description historique et pittoresque du grand cortège national suivi du compte rendu des fêtes et cérémonies publiques (Bruxelles: Jamar, 1848), $39 \mathrm{ff}$.

107 See, for example, E. Klynton, Vues générales sur l'établissement des sociétés agronomiques existantes, et sur celles à établir pour concourir au perfectionnement de l'agriculture (Gand: J.-N. Houdin, 1827), 25-7; Pierre Joigneaux, "Les fous et les sages en agriculture," La Feuille du Cultivateur 1 (1854-1855): 81.

108 Drouin, "Le 'moral' des plantes," 7.

109 Joigneaux, "Les fous et les sages," 81.

${ }^{110}$ Vanhaute and Van Molle, "Het einde van de overlevingslandbouw," 33.
} 
In any case, to assess the magnitude of the hopes that some people had pinned on exotic flora, one only needs to read the projections by the Frenchman Antoine Lasègue, who, in 1845, speculated excitedly that the world promised yet more botanical discoveries. ${ }^{11}$ We have seen that these dietary, horticultural, and sometimes industrial, hopes constituted a background necessary for the propagation and perpetuation of the dream of acclimatization. So, they were not new because, after a century at least, other authors had enriched this humus, simultaneously addressing the question of acclimatization. ${ }^{12}$ Publications by leading agronomists or horticulturists such as Abbot Rozier or, above all, André Thouin, are proof of this.

The former, who published the Cours complet d'agriculture pratique, théorique, économique et de médecine rurale et vétérinaire (Complete course of practical, theoretical, economic agriculture and rural and veterinary medicine) between 1781 and 1805, said:

The climate, the situation, are objects to consider. I am in no doubt that if we had imported mulberry tree seedlings from China to France, for example, it might have been impossible to propagate them; ... however, because they were sown first of all in the hot countries of Europe, they gradually became acclimatized; . . . and thus this tree adapted to the new environment gradually through the seeds; that is how the tulip tree was naturalized, and it became accustomed to spending winter in the open ground, even in the area surrounding Paris. Nature should never be constrained, but rather gently adapted to serving our needs and our fantasies; because it never make leaps. ${ }^{113}$

François Rozier, like Daubenton before him, also suggested a patient approach. The method: the progressive transplantation of successive young seedlings to "teach" them ${ }^{114}$ new living conditions. However, he acknowledged that this strategy was limited: in order to succeed, there must be a minimal analogy between the plant's original living conditions and the new conditions in the place where one wants it to grow. ${ }^{115}$ Here, Natura non facit saltum ${ }^{116}$ (Nature never makes leaps), the principle that marked the work of Carl Linnaeus, in the form of a subtle prosopopoeia, affixes the seal of incontestability to reasoning.

A figure with an even greater indisputable reputation than Rozier, André Thouin, Professor of culture at the Muséum d'Histoire naturelle (Museum of Natural History), in Paris, played

\footnotetext{
${ }^{111}$ Antoine Lasègue, Musée botanique de M. Benjamin Delessert: Notices sur les collections de plantes et la bibliothèque qui la composent, contenant en outre des documents et l'exposé des voyages entrepris dans l'intérêt de la botanique (Paris: De Fortin, 1845), 15-25.

112 Bourguet, "La collecte du monde," $181 \mathrm{ff}$.

113 Abbé Rozier, Cours complet d'agriculture pratique, théorique, économique et de médecine rurale et vétérinaire (Paris: Hôtel Serpente, 4, 1783), 337.

${ }^{114}$ Ibid., 337.

115 Ibid.

116 Patrick Tort, "Continuisime/discontinuisme," in Dictionnaire du Darwinisme et de l'Evolution, ed. Patrick Tort, 682-83 (Paris: PUF, 1996).
} 
a key role in the history of acclimatization. ${ }^{117}$ Some people even made him an "apostle"118 of acclimatization with a long and damaging influence on agriculture and horticulture. The fourth division of his Cours de culture et de naturalisation des végétaux (Course of culture and naturalization of plants), published in 1827, continued his Vues générales sur l'utilité d'acclimater en France des végétaux exotiques (General views on the utility of acclimatizing exotic plants in France). They constituted the introduction to his lessons. ${ }^{119}$ These pages bear the marks of an ideology of movement, of progress, possibly extended from the social sphere to the rest of living beings. ${ }^{120}$ Acclimatization, in conclusion, rooted in the conviction that life changes in accordance with the environment, would be nurtured by faith in the perfectibility of the living world and the possible influence of human ingenuity on the latter. ${ }^{121}$ In this, it would appear to be a pure product of the Enlightenment, carried by the French Revolution to the level of State scientific program. ${ }^{122}$

Nevertheless, in André Thouin's works one sees an undifferentiated use of the terms: with naturalize and acclimatize describing the same action. ${ }^{123}$ Here, on the one hand, he states that: "To naturalize a plant is to transport it from the place where it grows naturally to another place where, with the help of cultivation, we manage to acclimatize it so that it propagates there like native plants." 124 Better still, taking the example of the "guava tree," which he said prospered in Provence following a progressive habituation to French temperatures, he believed this indicated a modus operandi, suggesting that other plants in the "hot zone" could, with the same treatment, withstand frost without being damaged and, equally, produce seeds that would confer this resistance and become matrices of "perfected varieties." $25 \mathrm{~A}$ form of plasticity, transmissible to descendants, inherited from Buffon and Daubenton, ${ }^{126}$ was at the heart of his dream of acclimatization, which to a certain extent became an art requiring patience. ${ }^{127}$ Thouin saw in it a "vast field that opens up to our research, and how it would be possible to increase the scope of our agriculture, by naturalizing fruit trees alone; but they must not only be our only objective." 128 There, on the other hand, the author rounded off his words and revealed

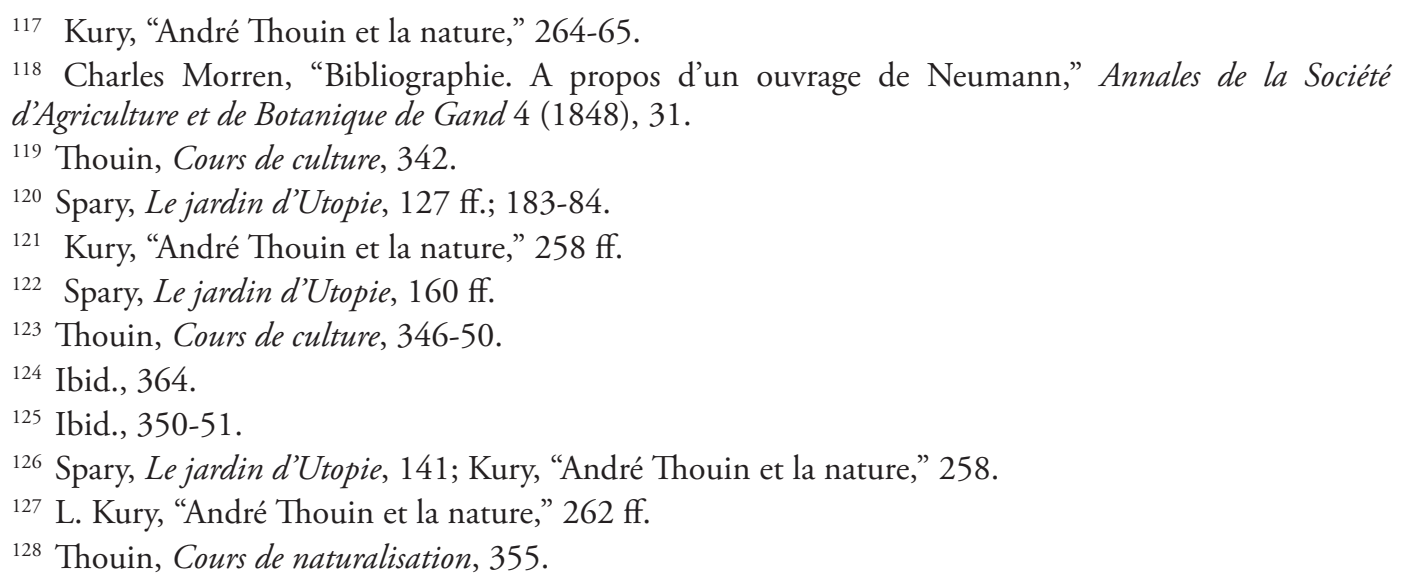


the limits of his optimism: ${ }^{129}$ he did admit that some plants will never become acclimatized to new living conditions; he recognized that "care"130 and "centuries" 131 may be required to achieve success; he knew that human knowledge was "still very inexact and not very extensive" and, ipso facto, encouraged people to take advantage of experience in this area. ${ }^{132}$ Moreover, he indicated the guidelines likely to guide the acclimatizers in their choices: terrestrial vegetables seem to "become naturalized"133 with more or less difficulty depending on their lifespan; plants with "tuberous, bulbous, fibrous or fleshy" 134 roots and ones that grow continuously do not overstep "the limits assigned to them by nature," 135 with ice "constricting the sap-conducting vessels" and dilating the liquid they contain and causing damage, etc. One should note that, separating acclimatization from pure empiricism, Thouin offered a physiological explanation here. In short, from the observation of what he considered to be facts, Thouin could conclude that, part of all the world's flora is destined to grow in permanently frozen areas, other plants in ice-free zones, and finally, the majority of plants grow "in all the intermediary regions." 136 This is where, according to him, the plants that we could "grow on our soil" are found ... ${ }^{137}$ And yet, as underlined by L. Kury, the Frenchman no longer recognized limits to acclimatization, and believed it was possible everywhere, worldwide, with the help of time. ${ }^{138}$ To "accustom [a plant] to a new way of life," 139 Thouin described his strategy: to make the plant adopt the growth rate of native plants or, if that is not possible, to plant it in a greenhouse, allow it to bear fruit and sow the seeds obtained. The plants produced by the latter will thus lose a few of their "native habits" and, repeatedly exposed to a new environment, generation after generation, it will be possible to "naturalize" them. ${ }^{140}$ Progressivity remains then, the cornerstone of the process. Thouin even created a research program out of the observation of these slow modifications. ${ }^{141}$ Furthermore, in keeping with the renewed peace between European nations, it was an international program he called for: a network of "naturalization depositories" would offer from North to South across the globe, staging posts where the progressive habituation

${ }^{129}$ Note that Lorelai Kury gives André Thouin an optimism that goes way beyond the limits that he seems to give acclimatization in the text we mentioned. See Kury, "André Thouin et la nature," 265; Kury, Histoire naturelle, 209-19.

130 Thouin, Cours de culture, 388.

131 Ibid.

132 Ibid.

133 Ibid.

${ }^{134}$ Ibid., 388-391.

135 Ibid., 391.

136 Ibid., 394.

137 Ibid.

${ }^{138}$ Kury, "André Thouin et la nature," 264-65.

139 Thouin, Cours de culture, 398.

140 Ibid., 448.

${ }^{141}$ Ibid., 458. 
of exotic plants would be assured, up to their final destination. ${ }^{142}$ People's well-being would depend on the fulfilment of these objectives, Thouin prophesized. ${ }^{143}$

It is impossible, when reading this, to avoid the question of the influence of Jean-Baptiste Lamarck (his contemporary and colleague at the Museum) on Thouin's ideas. Philippe Jaussaud, for example, clearly envisaged the transmission of acquired characteristics, at the heart of Thouin's acclimatization process as an expression of Lamarckism, ${ }^{144}$ whilst Lorelai Kury pointed out that Thouin's ideas preceded Lamarck's ${ }^{145}$ and Jean Gayon that the principle of the inheritance of acquired characteristics, despite being even older, was debated passionately in the eighteenth century by the proponents of the Enlightenment. ${ }^{146}$ In any event, Thouin started out and spent most of his career in an intellectual context-from Pierre Louis Maupertuis to Lamarckmarked by environmentalism and, as a result, conducive to the emergence of transformist thought.${ }^{147}$ but which, nevertheless, would not massively and plainly embrace transformism during many decades more. ${ }^{148}$ Let us add, however, that after Thouin's death, the standardbearer for acclimatization in France, Isidore Geoffroy Saint-Hilaire, showed a clear, though critical, penchant for Lamarck's environmentalist thinking. ${ }^{149}$ This other teacher from the Paris Museum, whose cautious transformism is well known, based his thinking on the conviction that the environment had a profound, though limited, influence on the living organisms, which "types" were regarded as stable. For many advocates of acclimatization, however, the limited-variability-of-type theory allowed adherence to this theory without threatening their fixism. ${ }^{150}$

That being said, we should note that alongside Thouin and Isidore Geoffroy Saint-Hilaire, who believed in acclimatization, the French scene also had fervent, prestigious opponents to this idea. These included Pierre Duchartre, Brisseau de Mirbel, mentioned earlier, and Abel Dupetit-Thouars. The last two mentioned, in this regard, a "pipe dream" ("une chimère"), a qualification that would become very popular when referring to acclimatization at that time. ${ }^{151}$ However, as underlined by Jean-Marc Drouin, not to believe does not mean to prove or,

\footnotetext{
142 Ibid., 459.

${ }^{143}$ Ibid.

144 Jaussaud and Brygoo, Du jardin au Muséum, 492.

145 Kury, Histoire naturelle, 219-20.

146 J. Gayon, "Hérédité des caractères acquis," in Lamarck, philosophe de la nature, ed. Pietro Corsi, Jean Gayon, Gabriel Gohau and Stéphane Tirard, 105-63 (Paris: PUF, 2006), 161-62.

147 Cédric Grimoult, Evolutionnisme et fixisme en France, Histoire d'un combat (Paris: CNRS Editions, 1998), 10-3.

148 Ibid., $115 \mathrm{ff}$.

149 Osborne, Nature, the Exotic, 66-70.

${ }^{150}$ Ibid., 70-1, 95.

${ }^{151}$ Drouin, "Le 'moral' des plantes," 8.
} 
above all, explain. ${ }^{152}$ So, could these opponents convince people or were they just making the situation even more confused?

\section{The Belgian scene (1830-1865)}

Firstly, let us point out that the sample of the Belgian general press that we consulted was certainly not indifferent to acclimatization. Whatever meaning journalists gave to this word, it helped propagate it, for many years, in an ambiguity rich in dreams.

Thus, until the late appearance, in their own pages, of a counter-speech, the Indépendant informed its readers about Spain's project to acclimatize the cacao palm, ${ }^{153}$ about France doing the same with the dromedary, ${ }^{154}$ and about the success of the acclimatization of the "daw" (or "dauw," of the family Equidae) at the Muséum d'Histoire naturelle, in Paris, ${ }^{155}$ etc. In 1837, this paper adopted, passing on a well-known antiphon, the words attributed to a Chinese thinker, very appropriate for encouraging farmers and patriots in projects of this type: "I think ... there is more merit in acclimatizing a new fruit than in building a hundred porcelain towers." 156

In the lay press we have read, there were very few misgivings regarding what was called "acclimatation." To our knowledge, it was not until the 1860s that the tone of this paper changed radically regarding this subject. And how it changed! To quote Isidore Geoffroy SaintHilaire, Chair of the Paris Acclimatization Society_ - "There is, as we see, . . . a happy emulation among the most advanced peoples, to add, through acclimatization, to the resources of their agriculture and their industry. Let this pacific rivalry produce results everywhere that we are justified in expecting"157 — in the end, acclimatization was simply considered a prince or a king's passing fad. The staggering losses that the experiences would have caused even led journalists from the famous Indépendance Belge to state that:

There is a sort of solidarity between the animal organism and the places where it develops, and that cannot be broken with impunity; animals and plants are as it were parasites of the different parts of the globe where they are born, must experience changes that will vary in magnitude increasing in accordance with how different the new destination is from their native country. ${ }^{158}$

\footnotetext{
152 Ibid., 8.

153 Indépendant, February 14, 1834.

154 Ibid., April 4, 1834.

155 Ibid., August 26, 1836.

156 Ibid., February 14, 1837.

157 Anonymous, "Revue scientifique de Paris," Indépendance Belge, October 19, 1860.

158 Ibid.
} 
Derisive, the journalist even dared to ensure the members of the French Acclimatization Society were fully aware of this reality. So, under the guise of patriotism, humanism and science, the opening of the Jardin d'Acclimatation (Acclimatization Garden) (1860) in Paris became, in the columns of the popular daily paper, a banal expression of the elites' taste for exotic exhibitions. ${ }^{159}$ This point of view was not so irrelevant since, according to Michael Osborne, the French Société d'Acclimatation (Society of Acclimatization), a mixture of scientists and science-loving bourgeois, owed much of its success to the support from the administration of Emperor Napoleon III. ${ }^{160}$

Three years later, in the same journal, an anonymous pen described one of his friends"my friend is the greatest acclimatizer in the world. He allows people to eat, but above all he wants people to acclimatize. He wants people to acclimatize animals, trees, fruit, flowers and vegetables"- when this friend was visiting Baron de Rothschild. Shunning the frivolities that he had been invited to engage in, the man apparently asked his host: "Where do you acclimatize, please?" Then, satisfied with what he saw, he exclaimed:

But what we were really happy to see and what really filled us with hope, were the vast, beautiful grounds of the park . . . where it would be so easy for Baron de Rothschild, honorary chair of the Acclimatization Garden Society, to have antelopes, cassowaries, curassows, and monals, which only need suitable forests to welcome them in order to become naturalized. This would be the great, authentic acclimatization. ${ }^{161}$

\section{The tone speaks for itself.}

Let us rewind three decades before the mocking by the most respected Indépendance Belge newspaper, examine more specialized sources and scrutinize the reflections of the Belgian scientific, horticultural and agricultural world regarding acclimatization.

Among the exhibitions that the Brussels Botanic Garden regularly organized, in 1833 it opened an enlightening competition entitled "To the farmer who, through authentic certificates, has proven that he has managed to acclimatize an exotic plant completely, which to date had not been able to withstand the weather in the kingdom. The certificates must state that the plant was subject to quite long tests to ensure that the success was not attributed to chance." ${ }^{162}$ It

159 On this particular aspect of nineteenth century zoos, see, for example: Annick Brauman and Marie Demanet, Le Parc Léopold, 1850-1950: Le zoo, la cité scientifique et la ville (Bruxelles: Archives d'Architecture Moderne, 1985), 9-24.

160 Osborne, Nature, the Exotic, 70-1.

161 Anonymous, "Courrier de Paris," Indépendance Belge, September 20, 1863.

162 Anonymous, "Expositions de la Société Royale d'Horticulture de Bruxelles," L'Horticulteur Belge 1 (1833-1834): 118. 
was understood that here it was a matter of rewarding acclimatization in the strict meaning of the term. A few years later, Pierre-Auguste Drapiez, a liberal French naturalist who moved to Belgium during the Restoration and co-founder of Brussels Botanic Garden, summoned to portray this institution, wrote "in accordance with its statutes, the purpose of [the Botanic Garden] is not just to look after a collection of living plants, [it] is obliged to attempt, through all kinds of tests, to acclimatize exotic plants that may be of use to the general economy. ..."163 What Drapiez did not say was that, with this, his botanic garden was only responding to the injunctions dictated by the State. These injunctions attested that acclimatization formed part of the Belgian administration's dreams.

At the same time, in the pages of the Horticulteur Belge, a journal edited by Michel Scheidweiler-a recent German immigrant and at that time Professor of Botany and Agronomy at the National Veterinary School, in Brussels ${ }^{164}$-, Link played a totally different tune. Admittedly, we already know that this Berliner had reported the lexical vagueness that surrounded the term acclimatization. In any case, whilst for him it was a matter of giving this word the meaning of getting a plant (or an animal) accustomed to new conditions of life, he wanted to point out that everything remained to be proven: no successful cases has ever been reported, he said, and those who believed they had, had probably been victims of an exercise in smoke and mirrors. Indeed, Link suggested that plants that people thought had been acclimatized would generally only have survived in a climate relatively similar to that of their place of origin, or spontaneously possessed a capacity to live in different conditions. Speaking about acclimatization was but an abuse of language, thus. As for carrying out tests with this objective, whether they were called acclimatization ${ }^{165}$ or something else, Link indicated several paths to take and enforced a wellknown perquisite: to learn both about the climate conditions of the plant's country of origin and those of its host country. ${ }^{166}$ Did Link and his reminder of climate limitations, mentioned by many other authors before him, more or less explicitly, announce the end of the dream of acclimatization sensu stricto, in any case in botanical, agricultural or horticultural publications in Belgium? In any event, his words indicated the widespread persistence of dreams or hopes.

At the start of the 1840s, the respectable Bulletin de l'Académie de Bruxelles made similar reflections, when it opened its pages to a German botanist. On this occasion, Philipp von

\footnotetext{
${ }^{163}$ Letter from Drapiez to the Liège City Mayor, 29 June 1837, Travaux publics 33418, Archives de la Ville de Bruxelles.

164 Denis Diagre-Vanderpelen, "Michel Scheidweiler et Henri Galeotti, les pères du genre Ariocarpus (Cactaceae)," in Mélanges offerts à Hossam Elkhadem par ses amis et ses élèves, ed. Frank Daelemans, JeanMarie Duvosquel, Robert Halleux and David Juste, 465-83 (Bruxelles: Archives et Bibliothèques de Belgique, 2007), 465-69.

165 During our research, this word only appeared in the translation of Link's text by the L'Horticulteur Belge.

${ }^{166}$ Heinrich Link, “De l'acclimatation des végétaux,” L'Horticulteur Belge 4 (1837): 337-42.
} 
Martius mentioned what he called the plant "paradise." 167 According to him, it was an area where a plant prospered, a zone itself contained in a larger space, but limited by latitude and altitude, where the plant could be kept relatively easily. ${ }^{168}$ Beyond these boundaries, this would not be possible. Without actually naming it, these words formed part of botanical geography, which was a field in full development, with its potentially insurmountable aspect in the form of strict "laws" of plant distribution. ${ }^{169}$

The volumes published by the Académie de Bruxelles (Academy of Brussels), the country's first forum for scientific sociability, also regularly contained articles by Charles Morren. Member of this prestigious institution, professor of botany at the University of Liège, Morren was imbued with the work of great French scientists, including Lamarck and Etienne Geoffroy Saint-Hilaire. ${ }^{170}$ Like many naturalists of the Age of Enlightenment ${ }^{171}$ he used to move freely between the sciences that were being increasingly readily divided up into pure and applied sciences. Morren deserves some attention for that reason but also because he contributed to maintaining a climate of doubt conducive to optimism regarding acclimatization.

First of all, in the agricultural journal he edited, when he mentioned the great variations that a species can display in accordance with its living conditions, ${ }^{172}$ or when he encouraged people to propagate exotic plants using seeds in order to produce different varieties, ${ }^{173}$ he supported the theory of the limited plasticity of living beings, which was widely held at that time, as well by supporters of transformism as by those of fixism. ${ }^{174}$ The lines he devoted to mayua (mashua), an edible South American tuber, illustrated this and remained, besides, as silent as many others on the intimate processes that govern this plasticity:

167 Philip von Martius, “Communication," Bulletin de l'Académie royale des Sciences et des Belles-Lettres de Bruxelles 9 (1842): 611-12.

168 Ibid., 610-14.

169 Bourguet, "La collecte du monde," 195; Kury, Histoire naturelle, 209.

170 See, on this point, Charles Morren, "Essais pour déterminer l'influence qu'exerce la lumière, sur la manifestation, et les développemens des êtres végétaux et animaux, dont l'origine a été attribuée à la génération directe, spontanée ou équivoque," Annales des Sciences naturelles, seconde série, 3-Zoologie (1835): 5-12.

${ }^{171}$ On the entanglement of sciences that we shall call "pure" and "applied," thereafter, but inseparable, at the end of the eighteenth century, we shall see Spary, Le jardin d'Utopie, 127-28.

${ }^{172}$ Charles Morren, "Notice sur la serradelle ou pied-d'oiseau," Journal d'agriculture pratique, d'économie forestière, d'économie rurale et d'éducation des animaux domestiques du Royaume de Belgique, publie sous la direction et par la rédaction principale de Monsieur Charles Morren 1 (1848): 180-91.

${ }^{173}$ Charles Morren, "Notice sur le topinambour, son histoire et des usages," Journal d'agriculture pratique, d'économie forestière, d'économie rurale et d'éducation des animaux domestiques du Royaume de Belgique, publie sous la direction et par la rédaction principale de Monsieur Charles Morren 1 (1848): 47-60.

${ }^{174}$ Osborne, Nature, the Exotic, 62-72. 


\begin{abstract}
We know that the potato has produced countless varieties. It is the fate of all expatriated plants, and the further a plant is moved ... from its place of origin, its creationary paradise, as described by $\mathrm{Ph}$. von Martius, the more variable it becomes: it is thus in the areas surrounding the cultivation areas that the varieties are most numerous. And here, in Belgium, we are at a very respectable distance from the "Popaya" Andes. Moreover, the varieties arise from seeds or successive plantations, increase in number, in proportion with the time in which experiments can be carried out. ${ }^{175}$
\end{abstract}

Reading these words, it is hard to avoid having agricultural daydreams about acclimatization, even in the strict sense of the word. And yet, the botany professor who willingly served as a historian for the transportation of useful vegetables, ${ }^{176}$ several years earlier, flew off the handle and attacked this hope, before, — and this is very telling-once again striking whilst the iron was hot, right before 1850 .

Firstly, again in the Journal d'Horticulture pratique, Morren echoed a debate on acclimatization, which took place in a Parisian horticultural society. Indeed, the Belgian botanist, an experimental scientist by nature, insisted that a "theoretician, a distinguished writer" had defended acclimatization, against hundreds of "practitioners" and pointed out the "fact" 177 that no plant, despite a secular presence, was ever acclimatized. ${ }^{178} \mathrm{Next}$, it was the annals of the Société royale d'Agriculture et de Botanique de Gand (Royal Society of Agriculture and Botany of Ghent) that were to open up, to his exasperation. So, in 1848, he flew into a rage, reviewing the work of the head gardener of the Muséum de Paris, Joseph Neumann:

Joseph Neumann quite rightly challenged the ideas that certain people, with outmoded opinions on progress in natural sciences, still put forward on the possibility of acclimatizing foreign plants. However, it allowed us to note that this time he stated that he was not the first person to fight acclimatization, and it was not Mr. Poiteau either who expressed this idea in 1830. This discussion dates back many years, ... . it was Pyramus de Candolle, in the third volume of his classic work on physiology ...., who described the true state of affairs. We still believe that in a book like Neumann's it is good to return to this false theory, which many people were taken in by and, unfortunately for our culture, is deeply ingrained in our populations. Clearly, by setting himself up as the apostle of acclimatization, André Thouin caused severe damage to agriculture, forestry economy and horticulture. ${ }^{179}$

175 Charles Morren, "Notice sur le Mayua des Péruviens (Tropaeolum tuberosum), plante alimentaire à tubercules féculifères, cultivable en Belgique," Bulletin de l'Académie royale des Sciences et des Belles-Lettres de Bruxelles 15 (1848): 350.

176 Ibid., 344-46.

177 Charles Morren, "Soins à donner aux artichauts au printemps, et, à ce sujet, deux mots sur l'Acclimatation ou Naturalisation des plantes," Journal d'agriculture pratique de la Belgique 1 (1844): 342. 178 Ibid., 341-43.

${ }^{179}$ Charles Morren, "Bibliographie," Annales de la Société Royale d'Agriculture et de Botanique de Gand 4 (1848): 30-1. 
In brief, for Morren, "it has been clearly demonstrated today that if naturalization is possible, acclimatization is something that nature has not achieved for the plant kingdom." 180

The background and the reason for these irritated clarifications by the Professor from Liège was the unique context of the potato crisis. ${ }^{181}$ In the 1840s, this crisis struck Belgium and Europe dramatically and led to — as proven by the Belgian media—a frenetic search for possible replacements for this tuber. ${ }^{182}$ Charles Morren, as a prestigious scientist, thus took responsibility for reframing what he regarded as mad expectations, quoting those who, before him, had questioned acclimatization sensu stricto. At the same time, he recalled how the confusion between the latter and naturalization was both common and harmful ${ }^{183}$ and the factors that, according to him, limited acclimatization, namely the climate and the soil. ${ }^{184}$

However, we should return to this once again, the emergence of varieties and the plasticity that this supposedly had encouraging virtues-for mulberry tree growers, for example. The same applied to this remark by Morren himself: the "isothermal lines," the different "climate zones"185 that Belgium is made up of remained poorly known. Was such ignorance, whilst firmly closing the door to acclimatizers stricto sensu, not slightly open to naturalization trials on the other hand? However, in the lexical fog we have already discussed, who can say if Charles Morren was received high and clear by his readers?

In the official report of the national agricultural exhibition in Brussels held in 1848, Morren and Baron Eugène de Lafontaine ${ }^{186}$ seemed to blow hot and cold, again.

\footnotetext{
${ }^{180}$ Charles Morren, "Culture du Bignonia lindleyi, jolie plante grimpante," Annales de la Société Royale d'Agriculture et de Botanique de Gand 4 (1848): 196. Italics in the original.

${ }^{181}$ Els Witte, "La construction de la Belgique 1828-1847," 142-44.

182 On the impact on Belgian State agricultural policy, see Vanhaute and Van Molle, "Het einde van de overlevingslandbouw," 33-47.

${ }^{183}$ Morren, "Culture du Bignonia lindleyi," 195-97.

${ }^{184}$ Charles Morren, "Revue rétrospective sur les cultures de la province de Liège pendant l'année 1847," Journal d'agriculture pratique, d'économie forestière, d'économie rurale et d'éducation des animaux domestiques du Royaume de Belgique, publie sous la direction et par la rédaction principale de Monsieur Charles Morren 1 (1848): 66-7.

${ }^{185}$ Ibid.

186 We failed to collect extensive data on Baron de Lafontaine. In 1865, he became a member of the board of Société d'Agriculture industrielle (joint-stock company). See Jean Stengers, ed., Index des Eligibles au Sénat (Bruxelles: Académie royale des Sciences, des Lettres et des Beaux-Arts de Belgique, 1975), 123.
} 
While the first one indicated, in a tone filled with optimism, that art can sometimes "beat nature" and delete the word "impossible" from the horticultural vocabulary ${ }^{187}$ and that "the 1848 exhibition proved that our vegetable horticulture . . . can . . . produce a large number of plants, which we did not think were likely to adapt to our climate"188 the second one declared:

that he [the farmer] is not allowed to defy the laws of nature with impunity in its wise dissemination of plants across different regions of the world. The observation of these rules led the renowned naturalist, Humboldt, to devise the concept of isotherms, which classified the geographic distribution of plants into specific zones. The facts ratified the data on the distribution of heat across the globe, in its correlation with the complete growth of plants, and the Belgian farmer seemed to have guessed the laws governing this, by defiantly approaching the cultivation of maize, whose producer country only shared the edge of our isotherm ${ }^{189}$

Over the course of that decade, another outstanding figure in Belgian agriculture, Michel Scheidweiler, a German-born professor who connected Belgium with German agronomy and botany, ${ }^{190}$ contributed to the great lexical confusion we discussed. He suggested, for example, that a Chilean plant "would be easy to acclimatize"—naturalize, in fact—in Belgium thanks to the analogies between the climates in certain parts of these two countries, ${ }^{191}$ or that yam farming could be attempted, because the plant would probably "acclimatize" to Belgium, if provided with slight protection from the cold, ${ }^{192}$ whilst specifying, moreover, that the "naturalization" of the alpaca in Russia was very doubtful, due to the thin air in its homeland. ${ }^{193}$

After the middle of the century, the horticultural and agricultural press provided a substantial harvest of reflections, which this time all concluded on the impossibility of acclimatization sensu stricto. Thus, Pierre Joigneaux, who, in the journal he edited, pleaded against the servile imitation of foreign agricultural practices not suited to Belgium, exclaimed, "Above all, let's all stick to our own country, to our own climate." He deplored the fact that "people had not noticed that life forms extremely specific to a given climate may be unable to live elsewhere,

${ }^{187}$ Charles Morren, "Rapport sur les légumes, produits agricoles cultivés comme objets de collection, les plantes rares et fleurs d'ornement et les instruments d'horticulture, constituant les deuxième, troisième, quatrième et cinquièmes classes du programme," in Rapport sur l'exposition nationale des produits de l'agriculture et de l'horticulture de 1848, 257-311 (Bruxelles: Parent, 1849): 266.

${ }^{188}$ Morren, "Rapport sur les légumes," 277.

189 Anonymous, "Rapport rédigé par le Secrétaire chargé d'apprécier les produits de la 1ère section," Rapport sur l'exposition nationale des produits de l'agriculture et de l'horticulture de 1848, 79-131 (Bruxelles: Parent, 1849), 89.

${ }^{190}$ In 1859, Michel Scheidweiler translated J. Schleiden's best-seller Die Pflanze und ihr Leben.

${ }^{191}$ Michel Scheidweiler, "De la Gunnera scabra," Journal d'Horticulture pratique de la Belgique 2 (1845): 200-01.

192 Michel Scheidweiler, "L'igname, Dioscorea; nouvelle plantes alimentaires," Chronique agricole rédigée et publiée par M.J. Scheidweiler, professeur d'agronomie 1 (1847-1848): 96-8.

193 Ibid., 367-69. 
either because of the ardor of the sap, or for a completely different reason," ${ }^{194}$ such as the soil or the climate, and so on. At the same time, an anonymous author wrote in the Journal d'Agriculture pratique, about Batata edulis, the sweet potato, for which he predicted a great future. On this occasion, he wrote: "originally from the tropics, from where it has spread imperceptibly towards temperate zones, now it can be divided up into numerous varieties, produced on different soils and climates (as long as they are situated on a given isotherm). More rustic varieties already existed, and repeated sowing should soon enable the growing of this replacement for the potato outside of the vegetable garden." ${ }^{195}$ Long periods of time, a selection of "varieties" grown from seed, and the influence of the climate and the soil converge, here too, to bury the hope for acclimatization to any kind of environment.

Charles Naudin, a naturalist from the Paris Muséum d'Histoire naturelle, wrote regularly in the Belgian horticultural press. In these pages, he also picked on the dreamers-furthermore, often speculators, he reported — ready to set out on the maddest naturalization adventures, ${ }^{196}$ the breadfruit tree and "a hundred more plants," which they did not even envisage that the French climate would quickly get the better of. ${ }^{197} \mathrm{He}$ said that, whilst some naturalizations were possible, over a long period of time, it remained forever impossible to accustom-an acclimatization, which he differentiated clearly from naturalization-a plant from a tropical climate to a cold climate, and vice versa. ${ }^{198}$ Besides, this conviction led to a conclusion with universalist overtones as utopian as acclimatization in the strict sense of the word seemed to be:

This means that nature has spread its gifts all over the globe; it has provided each country with its own specific products, in order to ask nations to lend each other things instead of shutting others out and remaining isolated. This diversity of products was and always will be the great motivation for travel and the most solid link for relations between peoples, which it will bring together sooner or later in a single family, irrespective of the differences in their morals, origins and languages. ${ }^{199}$

To finish this overview, let us give the floor to a final figure in Belgian agriculture and horticulture, François Rodigas. It was in a series of articles on agriculture in China, sent to the Feuille du Cultivateur, that he revealed his reflections on acclimatization. For him, it was

\footnotetext{
194 Pierre Joigneaux, "Les copistes en agriculture," La Feuille du Cultivateur 2 (1855-1856): 201-02.

195 Anonymous, "Acclimatation en Europe de quatre nouvelles variétés rustiques de Batates (Batatas utilis), provenant du Japon. Introduites par le Dr Von Sieboldt," Journal d'agriculture pratique, d'économie forestière, d'économie rurale et d'éducation des animaux domestiques du Royaume de Belgique 7 (1856): 44347.

${ }^{196}$ Charles Naudin, "Un mot à propos de la naturalisation des végétaux exotiques," Flore des Serres et des Jardins de l'Europe 11 (1856): 102.

197 Ibid., 102-04.

198 Ibid., 125-39.

199 Charles Naudin, "Effet d'un climat tropical sur les plantes de zones tempérées," Flore des Serres et des Jardins de l'Europe 12 (1857): 128.
} 
clear that "everyone knows, in fact, that each climate has its own vegetation that would not suit other climates," 200 although "we can talk all we like about the acclimatization of exotic plants, as soon as the normal atmospheric temperature drops below the average that the plant requires due to its nature, any attempts are totally useful and are reduced to empty words."201 The interest he aroused in Chinese agriculture was in line with a reasoning that we know well, and that many people then shared, as we know: only the existence of conditions-soil, climate, exposure, etc. ${ }^{202}$ - that are similar in both China and Belgium, can allow for successful introductions. He said that this was evidenced by the fact that, "China has produced plants that are already naturalized in our country, which adapt perfectly to the weather in our very variable seasons, without the need to subject them to what some people call acclimatization procedures." ${ }^{203}$ So, to him it had become clear that people could no longer simply do what they wanted with living beings.

\section{Conclusion: One can no longer freely interfere with nature ...}

One can no longer freely interfere with nature: a plant, even under pressure from human ingenuity, cannot go beyond its "nature" 204 and prosper, or simply survive, in places imposed by humans ... With no doubt, this is what the Belgians, who around 1865 abandoned the dream of a national silk culture, must have told themselves, after more than thirty years of contradictory rhetorical doubts, and also of firm convictions. This dream was rooted in the belief in the possibility of growing a rather delicate exotic plant on a large and profitable scale, that is, on the possibility of acclimatizing the white mulberry tree. Around 1865, in any case, the Belgian sericultural utopia had evaporated, like it would sooner or later do in many other North European countries.

One can no longer freely interfere with nature, that could also be, in a nutshell, the conclusion reached by the participants in the International Horticultural Congress held in Brussels in 1864, who were symptomatically asked to discuss a topic that had been suggested by Edouard Morren to the Fédération des Sociétés d'Horticulture de Belgique (Federation of Horticultural Societies of Belgium), the society that organized the event: ${ }^{205}$ "Acclimatization, naturalization,

\footnotetext{
${ }^{200}$ François Rodigas, "L'agriculture en Chine," La Feuille du Cultivateur 1 (1859): 553.

201 Rodigas, "L'agriculture en Chine," 633.

${ }^{202}$ Ibid., 711-14.

${ }^{203}$ Ibid., 566.

204 Anonymous, Bulletin du Congrès International d'Horticulture qui a été réuni les 24-26 April 1864 (Gand: C. Annoot-Braeckman, 1864), 70-2

205 Edouard Morren, L'acclimatation des plantes (Gand: Annoot-Braeckman, 1865), 4. This pamphlet was previously published in the Bulletin de la Fédération des Sociétés d'Horticulture de Belgique, in 1864.
} 
domestication of plants." ${ }^{206}$ If all those whose words we know seemed to agree on the need to differentiate between naturalization and acclimatization, and seemed to reject the latter, they would also testify to the irritating persistence of this old hope, in Europe. The study of the rhetoric in Belgium in the decades preceding this date, shows that the status of plant acclimatization was undoubtedly not very different from the one that prevailed in neighboring countries. German, English, French, and Belgian authors—possibly naturalized—who used to fill the pages of the specialized Belgian journals clearly indicate this. Indeed, the sources show, on the one hand, that the theory of limited flexibility of the type was widespread among those who took up the pen. On the other hand, they show that, in addition to the suggested lack of proven evidence of successful acclimatization, the development of botanical geography and the search for its "laws" justified the erosion of faith in acclimatization stricto sensu. Botanical geography, in fact, while not denying the production of more resistant varieties and breeds, at least limited the possibility of these phenomena to climatic zones.

How then was the acclimatization project - after the death of its main and sometimes incoherent defender, André Thouin, who passed on the great agronomic hopes of the Age of Enlightenment and the French Revolution—able to stay alive, in Belgium (and elsewhere), despite the discredit it suffered in the works by scientific luminaries of the day, such as Link and de Candolle?

First - this is purely hypothetical — this project survived probably because Belgian agriculture owed a great deal to the introduction of the potato in the eighteenth century. How couldn't farmers have entertained more hopes in foreign plants when they were constantly reminded of the contribution of some of them-namely potatoes—to Belgian agriculture? How, even more so, when the potato blight hit them hard in the 1840s?

Furthermore, one can ask if the foundation, by some salient naturalists and educated amateurs (led by Isidore Geoffroy Saint-Hilaire and supported by the French imperial administration), of the French Acclimatization Society in 1854-a significant number of whose foreign members were from Belgium — had not also what it needed to fuel the hopes of many people, that some qualified as irrational villagers, but who in fact counted many people from the social elites, as we know? Besides, accepting this raw and somewhat fallacious socializing hypothesis, would they have had the means (time, income, training, etc.) to welcome the emerging botanical geography we mentioned? Its "laws" and the work by men such as Humboldt and Candolle, to mention just a couple, which tried to identify these laws, somewhat threatened the dreams of universal acclimatization, admittedly, but who knew this if not the scientific elite?

206 Anonymous, "Bulletin du Congrès International," 64. 
Add to this the persistent lexical fog around the words acclimatation and naturalization, which the specialized literature was unable to dissipate and even encouraged, though unintentionally, we assume. Indeed, were these scholars and experts, who wrote in horticultural and agricultural popular science journals, crystal clear? Let us recall, for example, that at the 1864 Brussels Congress, one of them admitted that plants adapted, spontaneously, albeit very slowly, to changes in the climate; ${ }^{207}$ another spoke about acclimatization through the selection of new varieties; ${ }^{208}$ a third mentioned the limited plasticity of plants. It had been then all the great revolutions in the ignorance of the innate and the acquired in plant behavior, acknowledged by Thouin, ${ }^{209}$ that were able to justify, once and for all, the rejection of the old dream?

In fact, a few months after the Congress, Edouard Morren-who was unable to attend the 1864 Congress he had suggested the first topic to ${ }^{210}$ - told more about the acclimatization matter in Europe and the reason why it was not dead and buried. In a paper to the Bulletin de la Fédération des Sociétés d'Horticulture de Belgique he showed that, despite the apparent scientific consensus reached during this session, the matter was far from over. To him, plants were able to change some of their habits in the long run as long-cultivated plants, like many experiences and experimentations led all over Europe showed. ${ }^{211}$ Though not possible in natural conditions, nor with all the plants in all the places in the world, the Belgian professor in botany, a leading figure in agronomy and horticulture, plainly claimed that facts had proven that acclimatization was possible with long-cultivated, softened plants. Not only was it possible, he said, but it simply was one of the most fascinating questions of horticulture. ${ }^{212}$ To him, the consensus about the impossibility of acclimatization was but a shadow: when asked twice, many botanists would not be as assertive as they seemed to be, originally. According to Morren, in a nutshell, the acclimatization matter was in a "phase singulière" (odd situation), ${ }^{213}$ that Charles Darwin's ideas about the ever-transforming species helped to feed. ${ }^{214}$ The consensus was but a fake one and was adding its effects to the lexical fog.

Should we add that this first and somewhat sketchy study on the issue of plant acclimatization in Belgium raised even more questions? What to this issue after the 1864 Brussels Congress, where it was so hotly debated, and after Morren's attempt to fashion a status of the affairs? Whatever the case, a contribution by Docteur Clos, that Morren published in the journal he was editor-in-chief, shows that the lexical fog we have described, far from dissipating, became

\footnotetext{
207 Anonymous, "Bulletin du Congrès International," 76-80.

208 Ibid., 67.

209 Kury, "André Thouin et la nature," 262.

210 Morren, L'acclimatation, 4.

211 Ibid., 13-6.

212 Ibid., 4-5.

213 Ibid., 23.

${ }^{214}$ Ibid., 24.
} 
thicker. ${ }^{215}$ Better still, two years later, Edouard Morren, an assumed transformist, invoking Charles Darwin, the influence of the environment and selection, reported another case of plant acclimatization. ${ }^{216}$ All in all, this and many other clues suggest that the fate of the plant acclimatization issue was not sealed by the 1864 Brussels Congress and that the second breath of transformism probably contributed to the reflections on this topic. Indeed, although we know from the work of Michael Osborne that transformism was not a necessary condition of faith in acclimatization, we also know from the same author that the French Acclimatization Society had, however, an unusually large number of supporters of transformism. ${ }^{217}$ A more detailed work on the appropriation by horticulture and agronomy of Darwinian transformism could also indicate whether the dream of plant acclimatization would be rekindled in Belgium.

It should be added that if acclimatization and colonization, closely related issues in France, were only rarely dealt with together in Belgium before 1864, it was probably because Belgium did not yet have a colony. King's Leopold II Congo Free State (1885), followed by the creation of a real Belgian colony in the Congo (1908), might change something in the discussions on acclimatization. That is what more research will almost certainly find out.

Finally, we wonder whether the slow loss of legitimacy - if any-of acclimatization was not accompanied, in some cases, by the partial erosion of the universalism of the Age of Enlightenment. Would this universalism not progressively be covered by the emergence of "ethnicizing" nationalisms and raciology searching once again for "hard" foundations and scientific "laws"? Let us remember, supporting this daring suggestion, Charles Naudin's call, which, repudiating acclimatization in the strict sense, did however want to believe that the distribution of plants across the planet gave humanity, in its diversity, the order to change its riches, to share them and, thus, to enter an era of universal fraternity. Could this humanist wish not be conceived as the symptom of the erosion of part of the ideology that had carried acclimatization in its belly, a century earlier, for the benefit of a progressive solidification of identities, of essentialized nations, by science? In short, did Naudin not reply to some extent, in advance, to Antoine Fée's remarks at the International Horticultural Congress, during which as we know, the acclimatization "pipe dream" was destroyed? "Each of them [plants] has an idiosyncrasy ..., said Fée, its own unique way of being; it is subject to the action of the center where it lives; if that is not love of one's homeland, it is at very least the all-powerful influence of the native soil, which we ourselves are all happy to surrender to." ${ }^{18}$ Words which, it should be pointed out, would resonate with the conviction of Edouard Morren who, a few months

${ }^{215}$ Dominique Clos, "De la naturalisation et de l'acclimatation des végétaux," La Belgique horticole 15 (1865): 51-62.

${ }^{216}$ Edouard Morren, "Deux notes au sujet de l'évolution spontanée des variétés," La Belgique Horticole 17 (1867): 66-72.

217 Osborne, Nature, the Exotic, 90.

${ }^{218}$ Anonymous, "Bulletin du Congrès International," 108. Translation by the author. 
later, affirmed that any sudden attempt "to acclimatize Negroes in Siberia, or Greenlanders in Senegal" would be "unreasonable." ${ }^{219}$

\section{Acknowledgements}

The author would like to thank the Editors and reviewers of HoST for support and patience, as well as Dr. Lorelai Kury for being a source of inspiration.

\section{Competing interests}

The author has declared that no competing interests exist.

${ }^{219}$ Morren, L'acclimatation, 23. 